\title{
The Effects of Using Smartboard in Teaching and Learning a Foreign Language
}

\author{
Dr. Lina Fathi Sidig Sidgi
}

\author{
Al-Turath University College, Baghdad, Iraq \\ Received: 02 Sep 2021; Received in revised form: 01 Oct 2021; Accepted: 05 Oct 2021 \\ (C2021 The Author(s). Published by TheShillonga. This is an open access article under the CC BY license \\ (https://creativecommons.org/licenses/by/4.0/)
}

\begin{abstract}
The following study reviews the advantages attached to the use of smartboards in the facilitation of the teaching and learning process. The content covered below is therefore majorly categorized into two parts. The first part of the research will address the incorporation of this method in the teaching process of foreign languages and the resultant benefits of the same. Then, the research will look into the use of smartboards in the learning process and the effectiveness of the method to improve the understanding ability of the learners. The case study includes 10 participants who are learners from Saudi university who learn English as a foreign language. The participants of the research were picked via random sampling and were put under the study for a period of one week in order to acquire the intended information from them. Each of the above categories was composed of five learners. The research mostly incorporated questionnaires in both closed and open forms before the activity as well as after to retrieve the necessary data. This data also reflected on the student motivation and attitude towards learning English as a foreign language (Akbari, Z. 2015).
\end{abstract}

Keywords - Smartboard technology, learning efficiency, teaching efficiency, motivation, participation, performance.

\section{INTRODUCTION}

Current technological advances that have been developed have been adopted in almost all fields including the education system where the currently used methods of teaching and learning are slowly being replaced with computer technology.

The technology brings about various advantages as opposed to the rote system of education (Riaz, 2018). However, it is important to understand that the modern teaching and learning technology has to be used in harmony with the current methods of education in order to achieve the optimal results from the learners. The research will also compare and contrast the method of smartboards in the teaching/learning process to the other methods in the effort of showcasing the importance of these particular methods. There are various features of the smartboards interactive whiteboards that have been incorporated in the study. Relevant case samples that support the problem of the research will also be included in the study in line with the foreign language studies. Learning English is considered a difficult task especially for foreign language learners. Therefore, the following research, supports the recommendation of using smartboard technology in the teaching and learning processes of foreign studies.
Smartboard technology is a common practice of teaching and learning in various learning institutions which is aimed at improving the learner's motivation and participation especially while learning English as a foreign language.

The method does not only promote the motivation and participation of the learners in the learning activities but also equips the learners with better knowledge in the field of linguistics and offers them an opportunity to explore their ideas through critical thinking and evaluation. There are various advances that have been made especially in the learning of English language which is necessary in the current world that is faced with the modern demands and challenges of the language (Cook, 2016). As a result, several nations across the globe have opted for the use of internet and computer technology in the effort of integrating the learning process across the globe and benchmarking the activities of other learning institutions.

The operation of various institutions varies across the world with other factors affecting the practices. However, the e-learning process such as the use of smartboards cuts across the institutions due to its effectiveness in the teaching-learning process to both the teachers and the learners. The simplification of tasks as seen below makes the method a favorite for many academic institutions. The 
period of study basically involved the administration of language sessions through the use of smartboard technology as well as the conventional channels of teaching.

\subsection{Problem Statement}

The following research seeks to evaluate the effectiveness of using smartboard technology in the teaching and learning process focusing on foreign languages studies. The research intends to explore various aspects of the smart board technology based on the two perspectives of the learners and the teachers. The information on the two perspectives will then be used to draw the various discussions as well as conclusions thus establishing the importance of using this method of the learning process in various institutions. In addition, the research seeks to identify other channels of teaching foreign languages then making the relevant comparisons between the identified methods and the method of smartboard technology.

The inability to use or access the smartboard technology in marginalized regions where English as a foreign language is taught such as Saudi Arabia is another concern of the research (Gates, 2017). As much as technology has been recommended and argued to be effective, there is also the challenge of delivering this technology to the learners in the regions. The available smartboard technology is therefore supposed to be used by the teachers in the effort of developing better natural teaching approaches in order to improve the services. Student's chosen for the research study face the challenge of adopting the smartboard technology in the course of their studies which imply that they do not possess the skill and knowledge of operating and navigating the computer technology in the process of gaining linguistic knowledge.

\subsection{Research Questions}

The following research adopts three main questions which address the problem of the research and which are based upon the two aspects of the smartboard technology which are: the learner's perspective and the teacher's perspective. In addition, the research will use the questions below to investigate the necessity of using the smartboard technology in the current times especially while delivering foreign language studies as opposed to using other channels of teaching to serve the same purpose.

1) How does the smart board technology impact the teaching methods used in foreign language studies?

2) How does the smart board technology impact the learning ability of the students who pursue foreign language studies?

3) What are the advantages of using the smartboard technology in the teaching and learning environment as opposed to other possible channels incorporated in the foreign language studies?

\subsection{Research Objectives}

Based on the research questions that have been developed above, there are various objectives that need to be met in the course of the research with the help of various sources of reference. The research objectives will set the limits to the scope of the study in order to address the needs of the research problems. In addition, the research objectives will help to evaluate the discoveries made within the course of the research in the making of the research analysis and the relevant conclusions.

1) To understand the effectiveness of smartboard technology as a channel of teaching various language concepts to learners in a classroom setting.

2) To investigate the impacts that the smartboard technology has on the learners in their course of learning English as a foreign language.

3) To verify the advantages of incorporating smartboard technology in the teaching and learning environment over other methods that have been used to serve the same purpose.

\section{LITERATURE REVIEW}

Various researchers have drawn relevant arguments on the various teaching and learning processes that should be incorporated in learning institutions with the urge to improve the quality of education. However, there is no agreement that has been made about the common system of information administration that should be adopted especially with the current technology that has been heavily adopted in most of the learning institutions. The learning materials have been modified with the use of computer technology due to the ease of accessibility as well as the ability to constantly develop the teaching programs in the learning institutions. However, it is important to understand that the new technology is only a modification to the current systems of learning that are being used in the learning institutions with better features to develop the learners academically, especially in the field of linguistics (Akbari \& Razavi 2016). The e-learning practice brings about various learning options such as online learning, distant teaching, distant learning, online education as well as the online libraries.

The smartboard technology which is currently used in a number of learning institutions is much effective in comparison to the normal learning programs in terms of 
making the teaching of foreign languages easier and at the same time, improving the understanding ability of the learners. This technology is an interactive whiteboard technique which drives much interest to many institutions mainly due to its nature of cutting across the two phases of education which are the teaching and learning processes (Alshammari, 2016). Basically, the smartboard technology involves the use of a computer to generate the intended learning and teaching programs which are the projected to a whiteboard for a broader classroom view.

This technology is composed of the software and the hardware parts which when integrated, they ease the learning process and therefore can address a wide population of students at a time and help to elaborate the teaching materials better to the learners. The possession of the software and hardware systems in the classroom (the computer, the projector and the board), is the starting point to the teaching and learning process. There are simple connections which are required to complete the functionality of this technology and is technically easy to understand. Once the software content has been displayed on the smartboard, then the user will be required to use their finger as a navigation tool which allows them to open, close and load the intended files. In this case, the teacher is supposed to use the finger as the mouse to navigate the windows displayed on the board for the elaboration purposes.

Once the set-up is complete, the user will be able to easily navigate the internet, the software as well as the saved files on the computer. The display light on the smartboard and the font to be used is usually adjustable in order to fit the number of learners as well as the interest of the teacher. Just like the normal learning process, the user is able to take notes of the study subject which in this case are the foreign languages (Lasagabaster, D. 2017). However, unlike the normal whiteboards, the user is able to save the notes in the desired format into the files for future references. Also, the notes that are taken down can be printed to hardcopy in accordance with the desire of the user which is not the case with the normal whiteboards.

According to the above information, smartboard technology has been categorized into two parts: the hardware and the software parts. It is, however, important to understand that the two aspects of the technology work in harmony and thus, a defect on any of the parts might tamper with the whole process (Öz, 2015). Also, failure to make the right connections of the smartboards right from the computer to the screening part might also hinder the effective use of the technology

Other interesting and intrusive aspects of technological learning include the gaming practices which should serve as a motivational factor especially with the study of English as a foreign language. These are some of the aspects that have not been included in the conventional channels of information administrations and only proves the advantage of smartboard technology over the other forms of education channels. However, close monitoring, supervision, and guidance have to be integrated by the teachers to ensure the limits of technology are observed and that the technology advantage is used appropriately by the learners (Altun, 2015). Based on the above information, the possible merits of incorporating smartboard technology in the teaching-learning environment have been elaborated in detail by the research. The availability of images and videos while teaching will enable the learners to relate more to the linguistic concepts being relayed and in a memorable way rather than the monotonous voice of the teacher. Also, the responsibilities of the teachers have been made easier where computer technology acts as a second tutor for the learners.

Over the last decades, the English language has been adopted in various parts of the world which makes it top among the most used language across the globe. There are various factors that have contributed to the popularity of the language in various nations and among them, is the teaching of the English language in various academic institutions (Altun, 2015). In many regions where English is not the mother, language lessons have been administered under various prevailing circumstances and through various channels. However, today there is the incorporation of the smartboard technology meant to administer the foreign language studies and which over time has proven to be effective enough.

To understand the contributions of the technology in the learning and teaching processes of the foreign languages, one has to look into two perspectives of the same which are the learner's and teacher's perspective (Cattik \& Odluyurt 2017). This is mostly because the method cannot be qualified to be effective if it does not meet the interests of both sides. On the teaching perspective, the smartboard serves three main purposes which qualify it as an effective method of teaching. First, the method facilitates the conversation as well as the interaction between the teacher and the learners. Secondly, the technology helps to ignite deep research mostly with the aid of the internet thus developing new linguistic as well as cultural elements of the study. Thirdly, technology is a helpful tool for organizing the tutors teaching materials for a particular class. As mentioned earlier, the technology requires the use of a computer which stores various teaching files and documents in a comprehensive manner and which are easier to retrieve during the teaching process. As a result, 
much time is saved for the teaching practice. On the other hand, technology promotes the learning of foreign languages in a number of ways. First, the technology supports the cognitive process in the learning environment. Secondly, there are activities which support the oral and writing skills of the students and which receive a greater boost with the incorporation of computer technology. It is important to understand that the foreign language learning process is one that mostly incorporates the oral skills of the learner because, if a learner has to learn a new language, then they ought to follow proper pronunciations and in other cases, the right accents. Speaking a language will then help to improve the learner's ability to write it down.

That is the point when the smartboard technology is integrated in terms of easing the two processes. Thirdly, the technology supports the motivation and emulation of the learners in the process of learning especially when the rightful procedures are followed (Moeller \& Catalano 2015). The sense of operating the whole process with the sense of touch makes the learning process interesting and thus the psyche of the learners will definitely be improved in the course of the learning process. In addition, the research would retrieve analytical data from their recorded performances after undergoing a test at the end of the study period. The research analysis revealed a margin of 0.05 mean of their performances at the end of the activity in favor of the category that incorporated smartboard technology during the learning sessions. All the above advantages of smartboard technology are geared towards improving the learning and teaching of foreign languages. However, the method has its downsides which are also discussed in the course of the study.

\section{RESEARCH METHODS AND PROCEDURES}

The main method of data collection that was incorporated by the research was the administration of questionnaires to the chosen participants of the study. There was a total of 10 participants picked through random sampling and who was supposed to be the test of the research. To address the objectives of the study as well as the research problem as a whole, the researcher who was a teacher at the Saudi University teaching English put the ten students to test. The test was supposed to be administered after a period of two weeks where the participants were divided into groups of five. This added up to two groups one for the experimental purposes while the other group was a control group. Under the experimental class of the participants, the; learners were supposed to undergo foreign language learning sessions using the conventional means of information relay.
On the other hand, the control group was exposed to the use of smartboard technology as a teaching and learning the medium of English as a foreign language. Therefore, the first set of the questionnaire was rendered to the participants before the evaluation in the effort of understanding their learning abilities as well as their knowledge and opinion regarding the use of the smartboard technology as a channel of teaching and learning. On the other hand, the questionnaire was issued to the participant's right after the tests to evaluate their opinions of the same issue especially having considered their performance on those tests. In addition, the questionnaire was administered to two teachers of each group where they taught English as a foreign language in the University. The questionnaire was composed of the closed and the open questions which were administered under certain limits. The closed questions addressed specific questions of the research such as the rating of smartboard technology in a range of between 1-10 in order to acquire an honest opinion on the matter.

In addition, the closed questions incorporated the yes or no questions which were purposely placed to gauge the understanding of the learners about the whole idea of the research. The open questions, on the other hand, were the articulated questions asked to the learners but in this case, the participants were given a chance to express their thoughts, ideas as well as opinions relating to the effectiveness of the technology in the teaching and learning environment. Another important aspect of the questionnaires was the box sections which were evaluation questions that were supposed to be answered by either putting a tick across the boxes to show their agreement or putting a cross on the box to disagree with the statements. Using the method of the questionnaire in the following research contributed to the collection of oral data composed on thoughts and opinions of the randomly selected learners on the effectiveness of smart technology to the administration of lessons by the teachers linguistically.

Another important tool for collecting the data of the research was through the test result that was revealed a week after the collection of academic information (Brown, 2018). In order to successfully incorporate the information in the analysis part of the research, there was the need to consider the academic abilities of the learners at the university which was made possible by the teacher who was the research and who was well conversant with the student performance thus allowing the researcher to approve the participants of the research. The test was meant to reveal the actual figures of the smart board technology effectiveness by looking at how the learners performed in different circumstances. The first instance 
was the exposure of the learners to the smartboard technology while the other instance was the delivery of the lessons via the conventional means that have been used in the academic fields. In this second method of data collection, there was the need to include both the qualitative and quantitative methods of data collection in the effort of retrieving as much information from the participants as possible and at the same time, using analytical tables and figures to make the possible analysis.

All the participants that were selected for the study purposes were bilingual which insinuates that they were both conversant with the Arabic and English languages. This would enable them to respond properly to the questions and tests of the research. It is important to understand that the social-economic backgrounds of the participants for the research had an effect on the results of the test of the evaluation. This was because the method of random sampling that was incorporated in the completion of the research involved incorporating learners from various social economic backgrounds in Saudi Arabia.

Therefore, through the use of questionnaire survey as well as the active inspire methods, it was possible to generate the necessary data for the research. In the course of the experimental part of the research, there were various types of tests that were administered to the learners based on the concepts learned in the English language. There were tests for tenses, naming, sentence and phrase construction as well as the pronunciation tests. The teachers from the research group who administered the study sessions to the participants before the tests were also under certain instructions of approaching various concepts of the English language in the effort of establishing a common ground of the test. All the other possible factors influencing the learner performance were kept constant. The discovery and recording of the data retrieved from the study would then be used to generate various discussions of the research paper.

\section{RESEARCH FINDINGS AND DISCUSSION}

The information that was collected and recorded from the methods section was interpreted into figures in order to evaluate its effectiveness of using smartboard technology in teaching and learning process concentrating on foreign language setting. After studying the data, there were patterns which were recurrent and which led to the development of various discussions. According to the first hypothesis which addressed whether smartboard technology impact the teaching methods used in foreign language classroom, there was a mean difference of 0.05 which was realized between the two groups. The difference was in favor of the participants that were put under the smartboard method of learning. The mean data collected was based upon the general performance of the learners in both the control and the experimental group. The data retrieved through the first hypothesis was evidence that there is much more effective of incorporating the technology in the studies as compared to the conventional method (Fallah, 2016). The information was analytically represented as seen in the Table below.

Table 1. Results for the First Hypothesis Test for the Research

\begin{tabular}{lllccc}
\hline Groups & Mean & Standard Deviation & Difference Between the two Groups & Test Value & $\begin{array}{c}\text { Test Periodic } \\
\text { Value }\end{array}$ \\
\hline Control & 14.1 & 5.18 & Mean/s. deviation & 3.08 & 2.03 \\
\hline Experimental & 18.1 & 1.81 & $4 / 3.37$ & 3.08 & 2.03 \\
\hline
\end{tabular}

According to the information relayed in the first figure, there was an aggregate of 18.1 as the score for the experimental group which then translated to the standard deviation of 1.81. On the other hand, there was a standard deviation of 5.18 and a mean of 14.1 for the control group. The above results, therefore, resulted in a margin of 0.05 between the two groups of the research. The category of the null hypothesis was not put into consideration by the researcher in the drawing of the slight difference that translated to the general performance of the participants.

Apart from the tests that were employed in order to retrieve the useful information from the research problem, there was also the information that was relayed through the method of questionnaire administration which also reflected the attitude of both the learners as well as the teachers towards the incorporation of the technology in the facilitation of English studies. To understand the information better, the questionnaire response was presented qualitatively with clear responses being recorded from the research purposes. According to the information that was retrieved, most of the teacher responses brought forth more advantages of using the smartboard method of study than the negative sides of the same. The results also showed that there was more preference of the computer and e-learning technology in the learning environment compared to the conventional means that have been used 
in various academic institutions. According to figure two, there was also the learner perspective that was discovered which apart from reflecting in the tests, also presented the positive attitude owned by the learners towards the use of smartboard technology as a learning facilitator (Yapici \& Karakoyun, 2016). The question response also revealed the frequency of using the technology by both the learners as well as the teachers of English as a foreign language. This was among the problems identified with the research in the above sections and which was approved to be true. In addition, according to the results displayed in the table below, the behavioral tendencies to learn the English language was reflected from the participant's point of view. This reflected on the probability of using the smartboard technology in future to learn English as a foreign language.

\begin{tabular}{lcl}
\hline Standard Deviation & mean & Item \\
\hline $\begin{array}{lll}\text { Like English theory lessons } \\
0.69\end{array}$ & 1.61 & I like English more than any other university subject. \\
0.47 & 1.11 & English lessons are interesting. \\
0 & 1 & English is one of my favorite subjects. \\
Like English laboratory work & 1.11 & I like to do English lab activities. \\
0.47 & 1.16 & When I am working in the English lab, I feel I am doing something important. \\
0.51 & 1.05 & Conducting English experiments in university is fun. \\
0.23 & 1.27 & English is useful for solving everyday problems \\
Evaluative beliefs about university English \\
0.46 & 1.05 & People must understand English because it affects their lives \\
0.23 & 1 & English is one of the most important subjects for people to study \\
0 & 1.66 & I am willing to spend more time reading English books \\
Behavioral tendencies to learn English & \\
0.68 & 1.66 & I like trying to solve new problems in English \\
0.51 & 1.27 & If I had a chance, I would do a project in English \\
0.57 &
\end{tabular}

Fig.1. Participant Response to the Questionnaire

\section{RESEARCH SCOPE}

The research scope was limited to the needs of the study highlighted as the research objectives. There were various aspects of the study that were covered by the research but the needs of the research influenced the needs of the study. The research covered the various opinions and thoughts of the participants as well as a structured test in the effort of realizing the effectiveness of incorporating smartboard technology to facilitate the teaching and learning process of the foreign language studies. Specifically, the research investigated the views of the participants who are the learners at the Saudi university with the help of a teacher at the university as the researcher. In addition, the research covered the actual figures generated from the results recovered from the student performance in the tests to determine the effectiveness of the technology (Flanagan \& Shoffner, 2013). In addition, the research covered the information from the involved teachers answering to the effectiveness of the smartboard technology. However, there were other fields relative to the research problem that was not covered by the research such as the availability of the integrative smartboard technology to various academic institutions and the ability of both teachers and learners to navigate the technology.

\section{CONCLUSION}

The research conducted to investigate the effectiveness of the smartboard technology was successfully completed with the research having answered the three questions. The research revealed through the data collected from the two tests that smartboard technology has more advantages to facilitate the learning process in comparison to the other conventional methods. This was mostly as a result of the ability to integrate the learners more in the classroom environment and at the same time, improving the motivation and attitude of the learners towards the English language. Also, the data collected through the means of the administered questionnaires showed that the teachers in various learning institutions prefer to use the smartboard technology alongside other natural means of teaching in the effort of offering better knowledge to the learners. There is easy navigation as well as the order of teaching materials presented by a computer as compared to the whiteboards. However, other negative factors such as the unavailability of the technology and the difficulties to operate the smartboard seemed to be present in the course of the research. At the end of the research, is conclusive that the smartboard technology has more positive effects 
on the facilitation of learning English as a second language.

\section{REFERENCES}

[1] Flanagan, S., \& Shoffner, M. (2013). Teaching with (out) technology: Secondary English teachers and classroom technology use. Contemporary Issues in Technology and Teacher Education, 13(3), 242-261. Retrieved from https://www.learntechlib.org/primary/p/42121

[2] Velastegui, V., Cecicel, K., Guerrero, M., \& Elizabeth, M. (2016). Useful activities to enhance the speaking skills through the use of smart board in 3rd basic education year at Unidad Educativa Jean Piaget Albohispano high school during the school year 2016-2017 (Bachelor's thesis, Guayaquil: ULVR, 2016.).

[3] Yapici, I. Ü., \& Karakoyun, F. (2016). High School Students' Attitudes towards Smart Board Use in Biology Classes. Educational Research and Reviews, 11(7), 459-465. Retrieved from https://files.eric.ed.gov/fulltext/EJ1099956.pdf

[4] Fallah, M. (2016). The role of technology in EFL classroom: The case of the smart board. International Journal of Modern Language Teaching and Learning, 1(3), 90-98.

[5] Brown, L. (2018). The Effects of Technology versus No Technology On Sight Word Retention Of At-Risk Students. Retrieved from https://mdsoar.org/handle/11603/10959

[6] Cattik, M., \& Odluyurt, S. (2017). The Effectiveness of the Smart Board-Based Small-Group Graduated Guidance Instruction on Digital Gaming and Observational Learning Skills of Children with Autism Spectrum Disorder. Turkish Online Journal of Educational Technology-TOJET, 16(4), 84-102.

[7] Momani, M., Alshaikhi, T. S., \& Al-Inizi, T. H. (2016). The obstacles of using the smart board in teaching English at Tabuk secondary schools. Asian Journal of Educational Research, 4(3).

[8] Gates, B. K. (2017). Integrating Technology to Teach English/Language Arts to Elementary Deaf Students: A Case Study of a Teacher's Experiences and Practices. Lamar University-Beaumont.

[9] Preston, J. P., Wiebe, S., Gabriel, M., McAuley, A., Campbell, B., \& MacDonald, R. (2015). Benefits and challenges of technology in high schools: A voice from educational leaders with a Freire echo. Interchange, 46(2), 169-185.

[10] Altun, M. (2015). The integration of technology into foreign language teaching. International Journal on New Trends in Education and Their Implications, 6(1), 22-27.

[11] Riaz, S. (2018). A Review on the Role of Smart Board Technology in Education. VFAST Transactions on Education and Social Sciences, 15(2), 20-30.

[12] Bretsko, I., \& Kravchenko, T. (2018). Application of the smart board technologies for English language teaching.

[13] Cook, V. (2016). Second language learning and language teaching. Routledge.

[14] König, J., Lammerding, S., Nold, G., Rohde, A., Strauß, S., \& Tachtsoglou, S. (2016). Teachers' professional knowledge for teaching English as a foreign language: Assessing the outcomes of teacher education. Journal of Teacher Education, 67(4), 320-337.

[15] Kumaravadivelu, B. (2016). The decolonial option in English teaching: Can the subaltern act?. TESOL Quarterly, 50(1), 66-85.

[16] Moeller, A., \& Catalano, T. (2015). Foreign Language Teaching and Learning. International Encyclopedia Of The Social \& Behavioral Sciences, 327-333. Retrieved 2 July 2020, from https://digitalcommons.unl.edu/cgi/viewcontent.cgi?article= $1199 \&=\&$ context=teachlearnfacpub $\&=\&$ seiredir $=1 \&$ referer $=$ https $\% 253 \mathrm{~A} \% 252 \mathrm{~F} \% 252 \mathrm{Fscholar}$.google.c om\%252Fschola

[17] Nguyen, H. T. M., Nguyen, H. T., Van Nguyen, H., \& Nguyen, T. T. T. (2018). 12 Local challenges to global needs in English language education in Vietnam: The perspective of language policy and planning. In Un (intended) Language Planning in a Globalising World: Multiple Levels of Players at Work (pp. 214-233). Sciendo Migration.

[18] Matsuda, A. (Ed.). (2017). Preparing teachers to teach English as an international language. Multilingual Matters.

[19] Akbari, Z. (2015). Current challenges in teaching/learning English for EFL learners: The case of junior high school and high school. Procedia-Social and Behavioral Sciences, 199, 394-401. Retrieved from https://core.ac.uk/download/pdf/82125519.pdf

[20] Alrashidi, O., \& Phan, H. (2015). Education Context and English Teaching and Learning in the Kingdom of Saudi Arabia: An Overview. English Language Teaching, 8(5), 3344.

[21] Al-Nasser, A. S. (2015). Problems of English language acquisition in Saudi Arabia: An exploratory-cum-remedial study. Theory and Practice in Language Studies, 5(8), 16121619.

[22] Alrabai, F. (2017). The self-esteem of Saudi learners and their relationship to their achievement in English as a foreign language. English Linguistics Research, 6(4), 1-12. Retrieved sciedu.ca/journal/index.php/elr/article/view/12298

[23] Alharbi, H. A. (2015). Improving Students' English Speaking Proficiency in Saudi Public Schools. International Journal of Instruction, 8(1), 105-116.

[24] Koda, K., \& Yamashita, J. (Eds.). (2018). Reading to Learn in a Foreign Language: An Integrated Approach to Foreign Language Instruction and Assessment. Routledge.

[25] Al Asmari, A. A. (2015). Communicative language teaching in EFL university context: Challenges for teachers. Journal of Language Teaching and Research, 6(5), 976-984.

[26] Alshammari, A. K. (2016). Developing the English curriculum in the Kingdom of Saudi Arabia: Possibilities and challenges. Arab World English Journal (AWEJ) Vol, 6.

[27] Akbari, E., Naderi, A., Simons, R. J., \& Pilot, A. (2016). Student engagement and foreign language learning through online social networks. Asian-Pacific Journal of Second and Foreign Language Education, 1(1), 4.

[28] Suryasa, I. W., Prayoga, I. G. P. A., \& Werdistira, I. (2017). An analysis of students motivation toward English learning 
as a second language among students in Pritchard English academy (PEACE). International journal of social sciences and humanities, 1(2), 43-50.

[29] Lasagabaster, D. (2017). Language learning motivation and language attitudes in multilingual Spain from an international perspective. The Modern Language Journal, 101(3), 583-596.

[30] Dewaele, J. M., Witney, J., Saito, K., \& Dewaele, L. (2018). Foreign language enjoyment and anxiety: The effect of teacher and learner variables. Language Teaching Research, 22(6), 676-697.

[31] Akbari, O., \& Razavi, A. (2016). Using authentic materials in foreign language classrooms: Teachers' perspectives in EFL classes. International Journal of Research Studies in Education, 5(2), 105-116.

[32] Öz, H. (2015). Investigating the relationship between foreign language learning and call attitudes among EFL freshman students. Procedia-Social and Behavioral Sciences, 176, 1041-1049. 